\title{
FECAL SHORT-CHAIN FATTY ACIDS AT DIFFERENT TIME POINTS AFTER CEFTRIAXONE ADMINISTRATION IN RATS
}

\author{
Yu. V. HOLOTA', O. O. HOLUBENKOㄹ, A. M. OSTAPCHUK ${ }^{2}$, \\ T. M. SERHIYCHUK ${ }^{1}$, L. V. ZAKORDONETS ${ }^{3}$, G. M. TOLSTANOVA ${ }^{1}$ \\ ${ }^{1}$ Educational and Scientific Center "Institute of Biology and Medicine", \\ Taras Shevchenko National University of Kyiv, Ukraine; \\ ${ }^{2}$ D.K. Zabolotny Institute of Microbiology and Virology, National \\ Academy of Sciences of Ukraine, Kyiv; \\ ${ }^{3}$ Bogomolets National Medical University, Kyiv, Ukraine \\ e-mail: gtolstanova@gmail.com
}

Short-chain fatty acids (SCFAs) are major products of the microbial fermentation of dietary fiber in the colon. Recent studies suggest that these products of microbial metabolism in the gut act as signaling molecules, influence host energy homeostasis and play major immunological roles. In the present study, we defined the long-term effects of ceftriaxone administration on the fecal SCFAs concentration in Wistar rats. Ceftriaxone $(300 \mathrm{mg} / \mathrm{kg}$, i.m.) was administered daily for 14 days. Rats were euthanized in 1, 15 and 56 days after ceftriaxone withdrawal. Caecal weight and fecal concentration of SCFAs were measured by gas chromatography. Ceftriaxone administration induced time-dependent rats' caecal enlargement through accumulation of undigestable substances. One day after ceftriaxone withdrawal, the concentrations of acetic, propionic, butyric acids and total SCFAs were decreased 2.9-, 13.8-, 8.5-, 4.8-fold $(P<0.05)$, respectively. Concentration of valeric, isovaleric and caproic acids was below the detectable level. That was accompanied by 4.3-fold decreased anaerobic index and increased relative amount of acetic acid $(P<0.05)$. In 56 days, concentration of SCFAs was still below control value but higher than in 1 day (except for propionic acid). Anaerobic index was 1.3-fold lower $(P<0.05)$ vs. control. Conclusion: antibiotic therapy induced long-term disturbance in colonic microbiota metabolic activity.

Key words: antibiotics, ceftriaxone, colon, short-chain fatty acids (SCFAs).

$\mathrm{T}$ he interchange of low molecular weight metabolites between gut microorganisms and macroorganism have attracted a lot of attention during last years [1-3]. The gut microbiota affects predominantly host physiology by the production of short-chain fatty acids (SCFAs). SCFAs are saturated aliphatic organic acids that consist of one to six carbons of which acetate $(\mathrm{C} 2)$, propionate (C3), and butyrate (C4) are most abundant ( $\geq 95 \%)$. Acetate, propionate, and butyrate are present in an approximate molar ratio of 60:20:20 in the colon and stool [4]. Depending on the diet, the total maximum concentration of SCFAs decreases from 70 to $140 \mathrm{mM}$ in the proximal colon from 20 to $70 \mathrm{mM}$ in the distal colon [5].
These metabolites, especially butyrate, serve as an important source of energy for the intestinal epithelial cells, providing about $60-70 \%$ of their energy demand. Colonocytes from germ-free mice are in an energy-deprived state and exhibit decreased expression of enzymes that catalyze key steps in intermediary metabolism including the tricarboxylic acid cycle. Consequently, there is a marked decrease in $\mathrm{NADH} / \mathrm{NAD}^{+}$, oxidative phosphorylation, and ATP levels, that results in AMP-activated protein kinase activation, cyclin-dependent kinase inhibitor 1B phosphorylation and autophagy. When butyrate is added to germ-free colonocytes, it rescues their deficit in mitochondrial respiration and prevents them from undergoing autophagy [6].

(C) 2017 Holota Yu. V. et al. This is an open-access article distributed under the terms of the Creative Commons Attribution License, which permits unrestricted use, distribution, and reproduction in any medium, provided the original author and source are credited. 
Moreover, they indeed play major immunological roles both systemically and locally in the gut. This pathway involves the activation of SCFA-binding G-protein-coupled receptors (GPCRs). In 2003, GPR41 and GPR43 were deorphanised as SCFA receptors [7-9]. Anti-inflammatory functions refer to the property of SCFAs modulate immune cell chemotaxis, adhesion, production of reactive oxygen species and cytokines $[10,11]$. Butyrate elicits antiinflammatory effects via inhibition of interleukin (IL)-12 and upregulation of IL-10 in human monocytes [12]; inhibition of the tumor necrosis factor (TNF)- $\alpha$-induced nuclear translocation of the proinflammatory nuclear transcription factor- $\kappa \mathrm{B}(\mathrm{NF}-\kappa \mathrm{B})$ in human colorectal adenocarcinoma (HT-29) cell line [13] induction of colonic regulatory T cells differentiation, which suppresses the inflammatory and allergic response [14]. However, in sites of anaerobic bacteria infection or after the loss of intestinal epithelial integrity, high concentrations of SCFAs may lead to neutrophil accumulation and amplification of the inflammatory process [11].

Significant violations in gut and the whole body microecology often occur after using antibiotics and other chemotherapeutic agents that occupied a great place in modern medical practice [15]. There is the increasing concern that antibiotic exposure may have long-term consequences for immune tolerance of the gastrointestinal tract and susceptibility to pathogens, contributing to the development of inflammatory diseases [16]. The effect of antibiotic therapy on the fecal SCFAs level has been studied before [17-19], but most studies were conducted during or immediately after antibiotics administration. Therefore little is known about the duration of microbiota metabolic profile disorders caused by antibiotic therapy. The aim of this work was to determine the fecal SCFAs level at different time points after 14-day administration of cephalosporin antibiotic ceftriaxone in Wistar rats.

\section{Materials and Methods}

The experiments were performed on Wistar male rats (140-160 g, $n=12)$, which were bred and housed in the conventional animal facility of the ESC "Institute of Biology and Medicine" of Taras Shevchenko National University of Kyiv (Ukraine) under standard environmental conditions (12-h light/ dark cycle at a constant temperature of $22^{\circ} \mathrm{C}$ ). All animals had unlimited access to animal chow and tap water throughout the study. To normalize gut mi- crobiota, rats from all groups were kept in the same room and maintained by the same personnel. The study was approved by the animal committee of ESC "Institute of Biology and Medicine" Taras Shevchenko National University of Kyiv (Protocol No 8 issued in Nov, 2, 2015). The day 1 of the experiment is considered the first day of ceftriaxone or vehicle administration. Ceftriaxone (Ind. Stock Company Darnytsya, Ukraine) was administered for 14 days in a dose $300 \mathrm{mg} / \mathrm{kg}$ intramuscularly (i.m.). Control rats were treated with sterile water $(0.1 \mathrm{ml} / \mathrm{rat}$, i.m.). Caecal weight was measured directly one ( $15^{\text {th }}$ day of experiment) and 15 days ( $29^{\text {th }}$ day of experiment) after ceftriaxone withdrawal and calculated as $\%$ of body weight. The fecal concentration of SCFAs of rats was determined one ( $15^{\text {th }}$ day of experiment) and 56 days ( $72^{\text {nd }}$ day of experiment) after ceftriaxone withdrawal.

Fecal samples weighing $1 \mathrm{~g}$ were homogenized in $2 \mathrm{ml}$ of $0.02 \mathrm{~N} \mathrm{HCl}$ and then kept at room temperature for extraction during $30 \mathrm{~min}$ in air-tight containers to prevent the loss of volatile SCFA. Then samples were centrifuged for $10 \mathrm{~min}(11000 \mathrm{~g}) .300 \mu \mathrm{l}$ of supernatants were transferred to an autosampler vial for GC-MS analysis and added $100 \mu 1$ of $0.05 \%$ internal standard (4-methyl-valeric acid, Sigma-Aldrich, Germany).

The gas chromatographic (GC) analysis was carried out at the Center for collective usage at the D.K. Zabolotny Institute of Microbiology and Virology of NAS of Ukraine using an Agilent 6890N GC system (Agilent Technologies, USA) equipped with an automatic liquid sampler Agilent 7683B, (Agilent Technologies, USA). Separation was performed using a fused-silica capillary column with a free fatty acid phase DB_FFAP, $0.25 \mu \mathrm{m} \times 0.25 \mathrm{~mm} \times 30 \mathrm{~m}$ (Agilent Technologies Inc., USA). Helium was supplied as the carrier gas at a flow rate of $1 \mathrm{ml} / \mathrm{min}$. The initial oven temperature was $100{ }^{\circ} \mathrm{C}$, maintained for $5 \mathrm{~min}$, raised to $190^{\circ} \mathrm{C}$ at $10^{\circ} \mathrm{C} / \mathrm{min}$. The temperature of the injection port was $250^{\circ} \mathrm{C}$. The injected sample volume for GC analysis was $1 \mu \mathrm{l}$ with split ratio $1: 20$. The run time for each sample was $16 \mathrm{~min}$. A single quadrupole mass spectrometer Agilent, 5973 inert MSD (Agilent Technologies Inc., USA) was used for detection of SCFAs. Data handling was carried out with Chem Station Data Analysis D.01.02.16 software.

The SCFAs were identified on chromatograms by their specific retention times of standard SCFA mixture of acetic, propionic, $i$-butyric, $n$-butyric, 
$n$-valeric, $i$-valeric, $n$-caproic acids (Sigma-Aldrich, Germany) under the above GC conditions. To quantify the peak area in terms of concentration, the peak area was plotted against the peak area and concentration of the internal standard. Absolute quantities of SCFAs were normalized to sample mass and were expressed as $\mu \mathrm{mol} / \mathrm{g}$ faeces. The anaerobic index was counted as the proportion the sum of total propionate and butyrate to acetate concentration $\left(\mathrm{AI}=\left(\mathrm{C}_{3}+\mathrm{C}_{4}\right) / \mathrm{C}_{2}\right)$, relative SCFA abundance as proportion of each acid to the sum of total acetate, propionate and butyrate $\left(\mathrm{C}_{\mathrm{n}} / \sum\left(\mathrm{C}_{2}+\mathrm{C}_{3}+\mathrm{C}_{4}\right)\right)$.

Data were analyzed with the Statistica 6.0 software. Statistical significance was determined by the Student's $t$-test or nonparametric Mann-Whitney criterion where appropriate. $P$-values less than 0.05 were considered statistically significant. Data are presented as mean \pm SEM.

\section{Results and Discussion}

Although antibiotics are effective medications for the treatment of infections, antibiotic therapy often has adverse consequences to the host. Consistent with our previous study [20,21], ceftriaxone administration leads to profound changes in colonic microbiota in rats as well as in patients, immediately and long after antibiotic withdrawal. Moreover, the disturbance of the surface mucus barrier (level of glycoproteins) in the rat colon was observed long after the antibiotic therapy. We revealed also qualitative changes in the structure of glycan part of mucins, e.g. a decrease of hexoses and fucose content and increase of the level of sialation of mucus glycoproteins [20]. These changes are typical of inflammatory bowel diseases (IBD) [22]. However, the molecular basis of these alterations is not fully understood. It is important to find out the mechanisms by which antibiotic-induced microbial perturbations induce the disturbance of the intestinal barrier in remote terms after antibiotic therapy. We hypothesized that these disturbances involve the changes in gut microbiota metabolic profile.

As hindgut fermenters, rodents and rabbits comprise either a large cecum or colon, where food undergoing digestion is retained, mixed and fermented by microbes [23]. Undigested materials in the caecum are a potential source for intestinal bacteria to produce SCFAs. We observed caecal enlargement after ceftriaxone administration (Fig. 1). Thus one day after ceftriaxone withdrawal the caecal weight was 2.9-fold increased $(P<0.05)$ (Fig. $1, A)$, in 15 days -1.5 -fold $(P<0.05)$ (Fig. $1, B)$. Tulstrup et al. [24] have shown the increased caecum weight after amoxicillin and vancomycin administration. The development of an enlarged caecum is a typical feature in germ-free rodents [25]. It seems that caecal enlargement depends on the amount of accumulated substances that in the conventional animals should be degraded by microbial fermentation.

Further, we determined how ceftriaxone administration influences the fecal SCFAs concentrations. One day after ceftriaxone withdrawal the total concentration of the fecal SCFAs $\left(\Sigma\left(\mathrm{C}_{2}-\mathrm{C}_{6}\right)\right)$ was decreased 4.8-fold $(P<0.05)$ (Table).

Concentrations of acetic, propionic and butyric acids were 2.9-, 13.8- and 8.5-fold decreased
A



B

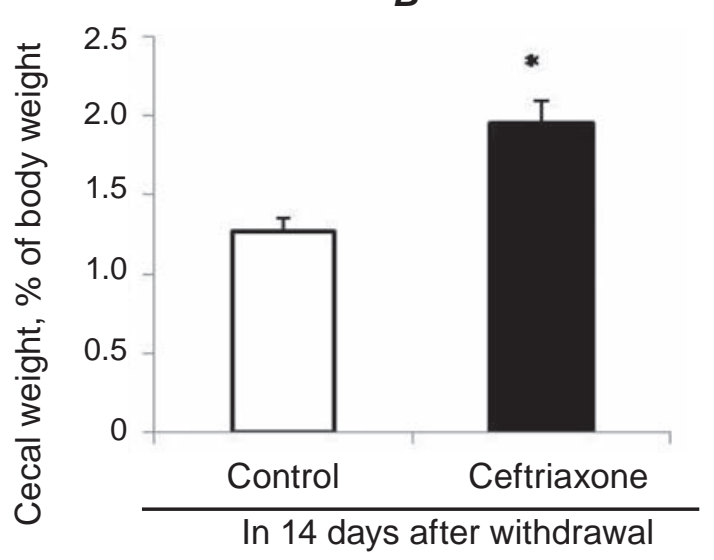

Fig. 1. Weight of rat caecum in 1 day (A) and 14 days (B) after ceftriaxone withdrawal $(300 \mathrm{mg} / \mathrm{kg}$, i.m., 14 days); $m \pm S E M ; n=12 ;{ }^{*} P<0.05$ vs. control value 
$(P<0.05)$, respectively. Concentrations of valeric, isovaleric and caproic acids were below the detectable level of parameters of chromatographic separation. These data are consistent with the results of Meijer-Severs et al. [26], in which treatment of healthy volunteers with ceftriaxone for 5 days resulted in a significant decrease in the fecal concentration of SCFAs on the $3^{\text {rd }}$ and $5^{\text {th }}$ day. Our previous study [27] showed that next day after ceftriaxone withdrawal the composition of colon parietal microbiota was not significantly changed. Moreover, the number of Propionibacterium and Bacteroides were even increased 1.6- and 2.3-fold $(P<0.05)$, respectively. Thus the observed changes in fecal SCFAs concentration represent disturbance of microbiota metabolic activity rather than its composition. According to the fact that SCFAs are the main energy substrates for the enterocytes, SCFAs loss might lead to disturbance of mucosal cells homeostasis in the rat colon. Moreover, the disruption of biochemical signaling between microbiota and host can profoundly affect inflammatory response leading to unresolving inflammation in the models of colitis, arthritis and asthma [28]. It should be noted that the decrease of butyrate-producing bacteria and SCFAs level detected in feces of patients with ulcerative colitis, indicated the role of intestinal dysbiosis and decrease of butyrate during colitis development [29]. Similar changes were also observed in patients with nosocomial diarrhea and Clostridium difficile-associated colitis [30]. A reduction in fecal butyrate has been found in patients with colorectal adenocarcinoma [31].
Acetic, propionic and butyric acids are most important among SCFAs. They are metabolic end products of proteolytic and saccharolytic microbiota used for the integrated assessment of its state [32]. We observed the 1.6-fold increased relative amount of acetic acid and 3.3- and 1.9-fold reduced proportion of propionic and butyric acids respectively $(P<0.05)$ one day after ceftriaxone withdrawal (Fig. 2). That was accompanied by 4.3 -fold decrease of the anaerobic index (Fig. 3). This index reflects the redox potential of the colon environment (balance between putatively anti-inflammatory properties of butyric and propionic acids and proinflammatory acetic acid) [32]. It was shown that butyrate and propionate were equipotent at inhibiting the transcription of NF- $\mathrm{\kappa B}$ and had anti-inflammatory properties, while acetate revealed a significantly lower efficiency [33]. In addition, propionate and butyrate, but not acetate, induced intestinal hormone release, that is an important mechanism for the regulation of host metabolism by microbiota [34]. Acetate might increase macrophage cells histone acetylation in vitro by end-product inhibition of histone deacetylases and activation of histone acetyltransferases. These changes promote activation of proinflammatory genes transcription and cytokines synthesis [35]. Thus observed changes may indicate a trend toward a proinflammatory condition in the colon.

Allowing for the fact that dysbiotic disturbance of mucosal microbiota were observed for a long time after ceftriaxone administration [27], we tested how these changes affect the SCFAs level in rat's feces.

Concentration of the short-chain fatty acids (SCFAs) in rats in 1 and 56 days after ceftriaxone (300 $\mathrm{mg} / \mathrm{kg}$, i.m., 14 days) withdrawal

\begin{tabular}{|c|c|c|c|}
\hline \multirow{3}{*}{ SCFAs } & \multicolumn{3}{|c|}{ Concentration ( $\mu \mathrm{mol} / \mathrm{g}$ wet faeces) } \\
\hline & \multirow{2}{*}{ Control } & \multicolumn{2}{|c|}{ Ceftriaxone, after withdrawal } \\
\hline & & in 1 day & in 56 days \\
\hline Acetic & $10.98 \pm 1.82$ & $3.79 \pm 1.03^{*}$ & $8.27 \pm 0.66^{\#}$ \\
\hline Propionic & $7.32 \pm 1.41$ & $0.53 \pm 0.19^{*}$ & $2.41 \pm 0.15^{*, \#}$ \\
\hline Butyric & $3.75 \pm 0.72$ & $0.44 \pm 0.14^{*}$ & $3.91 \pm 0.15^{\#}$ \\
\hline Valeric & $0.37 \pm 0.11$ & - & $0.27 \pm 0.03$ \\
\hline Isovaleric & $0.32 \pm 0.13$ & - & $0.38 \pm 0.02$ \\
\hline Caproic & $0.45 \pm 0.13$ & - & $0.17 \pm 0.09$ \\
\hline Total & $22.65 \pm 3.47$ & $4.75 \pm 1.36^{*}$ & $15.14 \pm 0.95^{\#}$ \\
\hline
\end{tabular}

* $P<0.05$ compare to control values; ${ }^{\#} P<0.05$ compared to values one day after ceftriaxone withdrawal; "-" acid concentration below detectable level of parameters of chromatographic separation. 


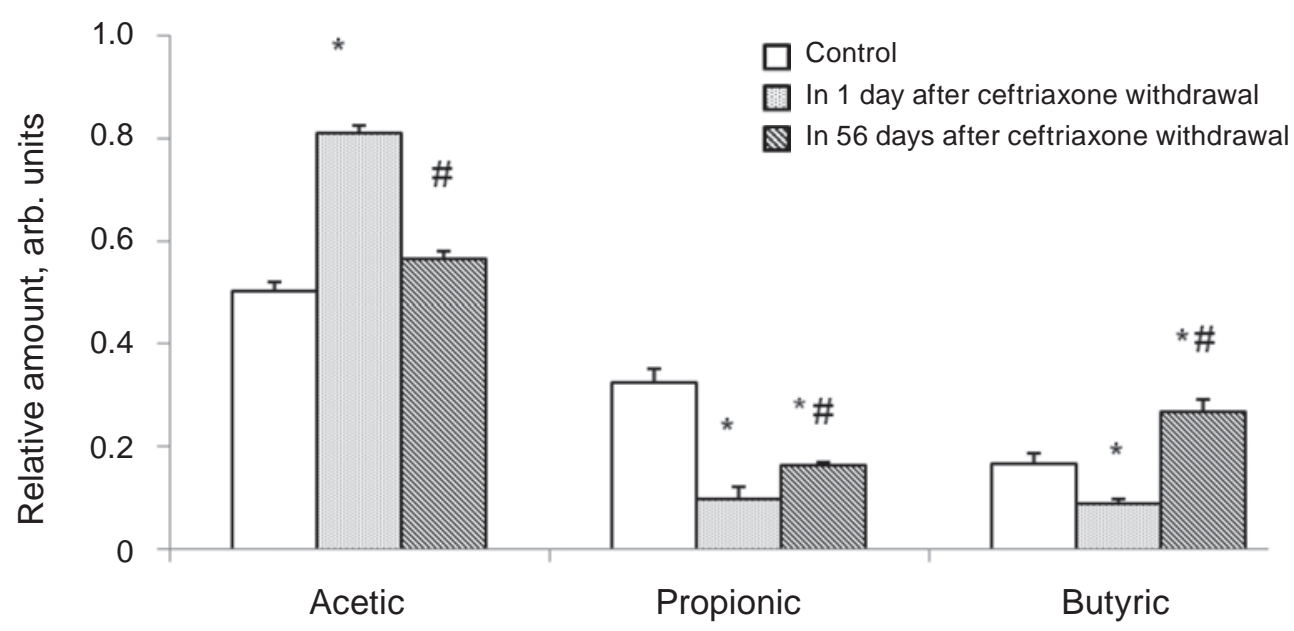

Fig. 2. The relative amount of acetic, propionic and butyric acids in 1 day and 56 days after ceftriaxone withdrawal (300 mg/kg, i.m., 14 days); $n=12 ; m \pm S E M ; * P<0.05$ vs. control values; $\# P<0.05$ vs. 1 day after ceftriaxone withdrawal

The concentration of fecal SCFAs in rats increased significantly 56 days after ceftriaxone withdrawal vs. the values observed one day after ceftriaxone withdrawal, but did not reach the control values. Moreover, the concentration of propionic acid was still significantly lower vs. control $(P<0.05)$ (Table). Interestingly, the amount of butyric acid corresponded to control value 56 days after ceftriaxone withdrawal.

The relative amount of acetic acid was 1.5fold decreased $(P<0.05)$ compared to the values observed one day after ceftriaxone withdrawal and corresponded to control values, while relative amount of propionic acid remained 2 -fold reduced $(P<0.05)$ vs. control. The relative amount of butyric acid increased 1.6-fold $(P<0.05)$ vs. control. According to similar anti-inflammatory properties of these acids, an increased level of butyric acid might occur due to a compensatory metabolic activation of butyrate-producing bacteria in response to a significant reduction in propionate formation. Propionate and butyrate are produced from hexose sugars by different microbial species. Only two species of Lachnospiraceae (Coprococcus catus and Roseburia inulinivorans) might switch from butyrate to propionate production on different substrates [36]. However, these changes do not lead to restoration of the redox status of colon lumen. The anaerobic index was 1.3-fold lower $(P<0.05) 56$ days after ceftriaxone withdrawal vs. the control values.

Thus, our results indicate that administration of ceftriaxone leads to a severe decrease in the total concentration of the fecal SCFAs in rats immedia-

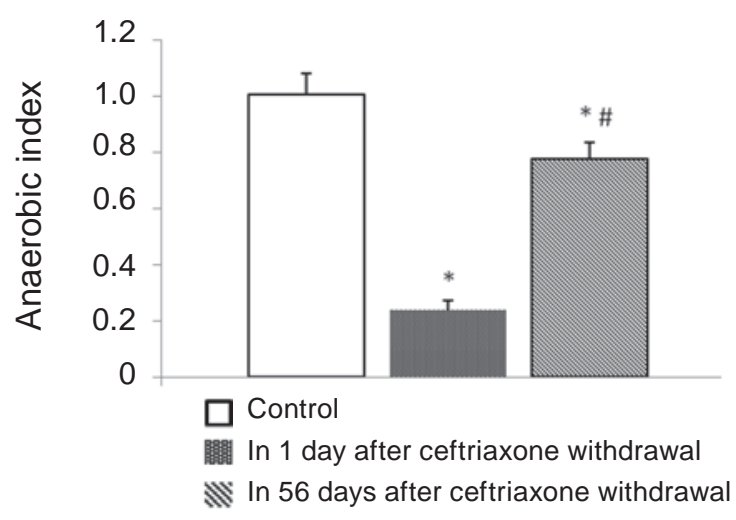

Fig. 3. The anaerobic index in 1 day and 56 days after ceftriaxone withdrawal $(300 \mathrm{mg} / \mathrm{kg}, i . \mathrm{m} ., 14$ days); $n=12 ; m \pm S E M ; * P<0.05$ vs. control values; \# $P<0.05$ vs. 1 day after ceftriaxone withdrawal

tely after antibiotic withdrawal. The most significant changes were observed in the concentration of propionic and butyric acids that led to the increase of relative amount of acetic acid. Reduction in the anaerobic index may indicate the inhibition of anaerobic and activation of conditionally pathogenic microorganisms after ceftriaxone withdrawal. These changes are stable over time. Even 56 days after ceftriaxone withdrawal the concentration of propionic acid and anaerobic index were still reduced significantly. Therefore antibiotic therapy leads to the stable long-term disturbances of colon microbiota metabolic activity in rats which underlied the pathogenesis of antibiotic-associated colon homeostasis 
disorders and might increase susceptibility to IBD development.

\section{ФЕКАЛЬНІ КОРОТКОЛАНЦЮГОВІ ЖИРНІ КИСЛОТИ В РІЗНІ СТРОКИ ПІСЛЯ ВВЕДЕННЯ ЦЕФТРИАКСОНУ ЩУРАМ}

\author{
Ю. В. Голота ${ }^{1}$, О. О. Голубенко ${ }^{2}$, \\ A. М. Остапчук², T. М. Сергійчук ${ }^{1}$, \\ Л. В. Закордонеиь ${ }^{3}$, Г. М. Толстанова ${ }^{1}$ \\ ${ }^{1}$ ННЦ «Інститут біології та медицини», \\ Київський національний університет \\ імені Тараса Шевченка, Україна; \\ ${ }^{2}$ Інститут мікробіології і вірусології \\ ім. Д. К. Заболотного НАН України, Київ; \\ ${ }^{3}$ Національний медичний університет \\ ім. О. О. Богомольця, Київ, Україна; \\ e-mail: gtolstanova@gmail.com
}

Коротколанцюгові жирні кислоти (КЛЖК) $€$ основними продуктами бактеріальної ферментації харчових волокон у товстій кишці. Недавні дослідження показали, що ці продукти мікробного метаболізму в кишечнику діють як сигнальні молекули, впливають на енергетичний гомеостаз організму хазяїна та відіграють головну роль в імунологічній відповіді. У цьому дослідженні визначали вплив цефтриаксону на концентрацію фекальних КЛЖК щурів лінії Вістар. Цефтриаксон (300 мг/кг, в/м) вводили щоденно впродовж 14 діб. Щурів умертвляли через 1, 15 і 56 діб після відміни цефтриаксону. Визначали масу сліпої кишки та концентрацію КЛЖК фекалій методом газової хроматографії. Введення цефтриаксону індукувало залежне від часу збільшення вмісту сліпої кишки щурів у зв'язку 3 накопиченням неперетравлених залишків. Через 1 добу після відміни цефтриаксону концентрація ацетатної, пропіонової, масляної кислот та загальна концентрація КЛЖК знижувалась в 2,$9 ; 13,8 ; 8,5 ; 4,8$ раза $(P<0,05)$ відповідно. Концентрація валеріанової, ізовалеріанової i капронової кислоти була нижче рівня детекції. Це супроводжувалося зниженням у 4,3 раза значення анаеробного індексу та збільшенням відносного вмісту оцтової кислоти $(P<0,05)$. Через 56 діб концентрація КЛЖК була все ще нижчою від контрольних значень, але вищою, ніж через одну добу (за винятком пропіонової кислоти). Анаеробний індекс був зниженим в 1,3 раза $(P<0,05)$ порівняно 3 контролем. Дійшли вис- новку, що антибактеріальна терапія спричинює тривале порушення метаболічної активності мікробіоти товстої кишки.

К л ю ч о в і с л о в а: антибіотики, цефтриаксон, товста кишка, коротколанцюгові жирні кислоти (КЛЖК).

\section{ФЕКАЛЬНЫЕ КОРОТКОЦЕПОЧЕЧНЫЕ ЖИРНЫЕ КИСЛОТЫ В РАЗНЫЕ СРОКИ ПОСЛЕ ВВЕДЕНИЯ ЦЕФТРИАКСОНА КРЫСАМ}

Ю. В. Голота 1 , А. А. Голубенко 2 , A. Н. Остапчук ${ }^{2}$, T. М. Сергейчук', Л. В. Закордонеи ${ }^{3}$, А. Н. Толстанова 1

'УНЦ «Институт биологии и медицины», Киевский национальный университет имени Тараса Шевченко, Украина;

${ }^{2}$ Институт микробиологии и вирусологии им. Д. К. Заболотного НАН Украины, Киев; ${ }^{3}$ Национальный медицинский университет им. А. А. Богомольца, Киев, Украина; e-mail: gtolstanova@gmail.com

Короткоцепочечные жирные кислоты (КЦЖК) являются основными продуктами бактериальной ферментации пищевых волокон в толстой кишке. Недавние исследования показали, что эти продукты микробного метаболизма в кишечнике действуют как сигнальные молекулы, влияют на энергетический гомеостаз организма хозяина и играют главную иммунологическую роль. В данном исследовании определяли влияние цефтриаксона на концентрацию фекальных КЦЖК крыс линии Вистар. Цефтриаксон (300 мг/кг, в/м) вводили ежедневно в течение 14 суток. Крыс умертвляли через 1, 15 и 56 суток после отмены цефтриаксона. Определяли массу слепой кишки и концентрацию КЦЖК в фекалиях методом газовой хроматографии. Введение цефтриаксона вызывало зависящее от времени увеличение массы слепой кишки крыс в связи с накоплением непереваренных остатков. Через 1 сутки после отмены цефтриаксона концентрация уксусной, пропионовой, масляной кислот и общая концентрация КЦЖК снижалась в 2,$9 ; 13,8 ; 8,5 ; 4,8$ раза $(P<0,05)$ соответственно. Концентрация валериановой, изовалериановой и капроновой кислот была ниже уровня детекции. Это сопровождалось снижением в 4,3 раза значения анаэробного индекса и увели- 
чением относительного содержания уксусной кислоты $(P<0,05)$. Через 56 суток концентрация КЦЖК была все еще ниже контрольных значений, но выше, чем через 1 сутки (за исключением пропионовой кислоты). Анаэробный индекс был снижен в 1,3 раза $(P<0,05)$ по сравнению с контролем. Сделан вывод о том, что антибактериальная терапия вызывает длительное нарушение метаболической активности микробиоты толстой кишки.

Ключевы е слова: антибиотики, цефтриаксон, толстая кишка, короткоцепочечные жирные кислоты (КЦЖК).

\section{References}

1. Mathewson ND, Jenq R, Mathew AV, Koenigsknecht M, Hanash A, Toubai T, OraveczWilson K, Wu SR, Sun Y, Rossi C, Fujiwara H, Byun J, Shono Y, Lindemans C, Calafiore M, Schmidt TC, Honda K, Young VB, Pennathur S, van den Brink M, Reddy P. Gut microbiomederived metabolites modulate intestinal epithelial cell damage and mitigate graft-versushost disease. Nat Immunol. 2016; 17(5): 505-513.

2. Vogt SL, Peña-Díaz J, Finlay BB. Chemical communication in the gut: Effects of microbiotagenerated metabolites on gastrointestinal bacterial pathogens. Anaerobe. 2015; 34: 106-115.

3. Lee WJ, Hase K. Gut microbiota-generated metabolites in animal health and disease. Nat Chem Biol. 2014; 10(6): 416-424.

4. Wong JM, de Souza R, Kendall CW, Emam A, Jenkins DJ. Colonic health: fermentation and short chain fatty acids. $J$ Clin Gastroenterol. 2006; 40(3): 235-243.

5. den Besten $G$, van Eunen $K$, Groen $A K$, Venema K, Reijngoud DJ, Bakker BM. The role of short-chain fatty acids in the interplay between diet, gut microbiota, and host energy metabolism. J Lipid Res. 2013; 54(9): 2325-2340.

6. Donohoe DR, Garge N, Zhang X, Sun W, O'Connell TM, Bunger MK, Bultman SJ. The microbiome and butyrate regulate energy metabolism and autophagy in the mammalian colon. Cell Metab. 2011; 13(5): 517-526.

7. Brown AJ, Goldsworthy SM, Barnes AA, Eilert MM, Tcheang L, Daniels D, Muir AI, Wigglesworth MJ, Kinghorn I, Fraser NJ, PikeNB, Strum JC, Steplewski KM, Murdock PR, Holder JC, Marshall FH, Szekeres PG, Wilson S, Ignar DM, Foord SM, Wise A, Dowell SJ. The
Orphan G protein-coupled receptors GPR41 and GPR43 are activated by propionate and other short chain carboxylic acids. J Biol Chem. 2003; 278(13): 11312-11319.

8. Le Poul E, Loison C, Struyf S, Springael JY, Lannoy V, Decobecq ME, Brezillon S, Dupriez V, Vassart G, Van Damme J, Parmentier M, Detheux M. Functional characterization of human receptors for short chain fatty acids and their role in polymorphonuclear cell activation. J Biol Chem. 2003; 278(28): 25481-25489.

9. Nilsson NE, Kotarsky K, Owman C, Olde B. Identification of a free fatty acid receptor, FFA2R, expressed on leukocytes and activated by short-chain fatty acids. Biochem Biophys Res Commun. 2003; 303(4): 1047-1052.

10. Kim CH, Park J, Kim M. Gut microbiota-derived short-chain Fatty acids, $\mathrm{T}$ cells, and inflammation. Immune Netw. 2014; 14(6): 277-288.

11. Vinolo MA, Rodrigues HG, Nachbar RT, Curi R. Regulation of inflammation by short chain fatty acids. Nutrients. 2011; 3(10): 858-876.

12. Säemann MD, Böhmig GA, Osterreicher $\mathrm{CH}$, Burtscher H, Parolini O, Diakos C, Stöck1 J, Hörl WH, Zlabinger GJ. Anti-inflammatory effects of sodium butyrate on human monocytes: potent inhibition of IL-12 and up-regulation of IL-10 production. FASEB J. 2000; 14(15): 2380-2382.

13. Yin L, Laevsky G, Giardina C. Butyrate suppression of colonocyte NF-kappa B activation and cellular proteasome activity. $J$ Biol Chem. 2001; 276(48): 44641-44646.

14. Furusawa Y, Obata Y, Fukuda S, Endo TA, Nakato G, Takahashi D, Nakanishi Y, Uetake C, Kato K, Kato T, Takahashi M, Fukuda NN, Murakami S, Miyauchi E, Hino S, Atarashi K, Onawa S, Fujimura Y, Lockett T, Clarke JM, Topping DL, Tomita M, Hori S, Ohara O, Morita T, Koseki H, Kikuchi J, Honda K, Hase K, Ohno H. Commensal microbe-derived butyrate induces the differentiation of colonic regulatory T cells. Nature. 2013; 504(7480): 446-450.

15. Jernberg C, Löfmark S, Edlund C, Jansson JK. Long-term impacts of antibiotic exposure on the human intestinal microbiota. Microbiology. 2010; 156(Pt 11): 3216-3223.

16. Shaw SY, Blanchard JF, Bernstein CN. Association between the use of antibiotics and new diagnoses of Crohn's disease and ulcerative colitis. Am J Gastroenterol. 2011; 106(12): 21332142. 
17. Høverstad T, Carlstedt-Duke B, Lingaas E, Norin E, Saxerholt H, Steinbakk M, Midtvedt T. Influence of oral intake of seven different antibiotics on faecal short-chain fatty acid excretion in healthy subjects. Scand $J$ Gastroenterol. 1986; 21(8): 997-1003.

18. Gustafsson A, Lund-Tønnesen S, Berstad A, Midtvedt T, Norin E. Faecal short-chain fatty acids in patients with antibiotic-associated diarrhoea, before and after faecal enema treatment. Scand J Gastroenterol. 1998; 33(7): 721-727.

19. Bender A, Breves G, Stein J, Leonhard-Marek S, Schröder B, Winckler C. Colonic fermentation as affected by antibiotics and acidic $\mathrm{pH}$ : Application of an in vitro model. Z Gastroenterol. 2001; 39(11): 911-918.

20. Holota YuV, Olefir YaA, Dovbynchuk TV, Tolstanova GM. Carbohydrate composition of rat intestine surface mucus layer after ceftriaxone treatment. Ukr Biochem J. 2016; 88(6): 35-44.

21. Zakordonets L, Tolstanova G, Yankovskiy D, Dyment $\mathrm{H}$, Kramarev S. Different regimes of multiprobiotic for prevention of immediate and delayed side effects of antibiotic therapy in children. Res J Pharmac Biol Chem Sci. 2016; 7(3): 2194-2201.

22. Campbell BJ, Yu LG, Rhodes JM. Altered glycosylation in inflammatory bowel disease: a possible role in cancer development. Glycoconj J. 2001; 18(11-12): 851-858.

23. Xiao J, Metzler-Zebeli BU, Zebeli Q. Gut Function-Enhancing Properties and Metabolic Effects of Dietary Indigestible Sugars in Rodents and Rabbits. Nutrients. 2015; 7(10): 8348-8365.

24. Tulstrup MV, Christensen EG, Carvalho V, Linninge C, Ahrné S, Højberg O, Licht TR, Bahl MI. Antibiotic Treatment Affects Intestinal Permeability and Gut Microbial Composition in Wistar Rats Dependent on Antibiotic Class. PLoS One. 2015; 10(12): e0144854.

25. Loesche WJ. Effect of bacterial contamination on cecal size and cecal contents of gnotobiotic rodents. J Bacteriol. 1969; 99(2): 520-526.

26. Meijer-Severs GJ, Van Santen E, Meijer BC. Short-chain fatty acid and organic acid concentrations in feces of healthy human volunteers and their correlations with anaerobe cultural counts during systemic ceftriaxone administration. Scand J Gastroenterol. 1990; 25(7): 698-704.
27. Holota Y, Dzyubenko N, Ostapchuk A, Dovbynchuk T, Serhiychuk T, Putnikov A, Kaji I, Tolstanova G. Long-Term Effect of Antibiotic Therapy on Colonic Levels of Short-chain Fatty Acids (SCFA), FFA2 and FFA3 Receptors. The 15th Int. Conf. of Ulcer Research. Ottawa, Canada, 2015. P. 48.

28. Maslowski KM, Vieira AT, Ng A, Kranich J, Sierro F, Yu D, Schilter HC, Rolph MS, Mackay F, Artis D, Xavier RJ, Teixeira MM, Mackay CR. Regulation of inflammatory responses by gut microbiota and chemoattractant receptor GPR 43 . Nature. 2009; 461(7268): 1282-1286.

29. Machiels K, Joossens M, Sabino J, De Preter V, Arijs I, Eeckhaut V, Ballet V, Claes K, Van Immerseel F, Verbeke K, Ferrante M, Verhaegen J, Rutgeerts P, Vermeire S. A decrease of the butyrate-producing species Roseburia hominis and Faecalibacterium prausnitzii defines dysbiosis in patients with ulcerative colitis. Gut. 2014; 63(8): 1275-1283.

30. Antharam VC, Li EC, Ishmael A, Sharma A, Mai V, Rand KH, Wang GP. Intestinal dysbiosis and depletion of butyrogenic bacteria in Clostridium difficile infection and nosocomial diarrhea. J Clin Microbiol. 2013; 51(9): 28842892.

31. Chen HM, Yu YN, Wang JL, Lin YW, Kong X, Yang CQ, Yang L, Liu ZJ, Yuan YZ, Liu F, Wu JX, Zhong L, Fang DC, Zou W, Fang JY. Decreased dietary fiber intake and structural alteration of gut microbiota in patients with advanced colorectal adenoma. Am J Clin Nutr. 2013; 97(5): 1044-1052.

32. Ardatskaya MD, Minushkin ON. Modern principles of diagnostics and pharmacological correction. Gastroenterology, Suppl. J. Consilium Medicum. 2006; 8 (2): 4-17. (In Russian).

33. Tedelind S, Westberg F, Kjerrulf M, Vidal A. Anti-inflammatory properties of the short-chain fatty acids acetate and propionate: a study with relevance to inflammatory bowel disease. World J Gastroenterol. 2007; 13(20): 2826-2832.

34. Lin HV, Frassetto A, Kowalik EJ Jr, Nawrocki AR, Lu MM, Kosinski JR, Hubert JA, Szeto D, Yao X, Forrest G, Marsh DJ. Butyrate and propionate protect against diet-induced obesity and regulate gut hormones via free fatty acid receptor 3 -independent mechanisms. PLoS One. 2012; 7(4): e35240. 
35. Kendrick SF, O'Boyle G, Mann J, Zeybel M, Palmer J, Jones DE, Day CP. Acetate, the key modulator of inflammatory responses in acute alcoholic hepatitis. Hepatology. 2010; 51(6): 1988-1997.
36. Reichardt N, Duncan SH, Young P, Belenguer A, McWilliam Leitch C, Scott KP, Flint HJ, Louis P. Phylogenetic distribution of three pathways for propionate production within the human gut microbiota. ISME J. 2014; 8(6):1323-1335.

Received 13.12.2016 